\title{
Wzajemna percepcja mocarstw oraz jej znaczenie dla rozwoju amerykańsko-chińskich relacji bilateralnych
}

\section{Wprowadzenie}

Obecnie jednym z większych wyzwań dla przyszłości i stabilności relacji bilateralnych oraz multilateralnych jest poprawne odczytanie oraz zinterpretowanie wzajemnych interesów narodowych. Jak podkreślił Hans Morgenthau, cele polityki zagranicznej muszą być definiowane na warunkach interesu narodowego, który z kolei wedle szkoły realizmu politycznego jest określany jako: synonim przetrwania, bezpieczeństwa, potęgi i jej pochodnych. Również były sekretarz stanu USA Henry Kissinger zwracał uwagę na problem kalkulacji interesu narodowego, który nie jest oczywisty sam z siebie. Należy bowiem pamiętać, że siła danego narodu i interes narodowy stanowią jedne z najtrudniejszych do dokładniejszego oszacowania elementy stosunków międzynarodowych. Natomiast większość wojen wybucha w wyniku błędnej oceny układu sił i wewnętrznych nacisków.

W nawiązaniu do powyższego akapitu wyłania się jeszcze jeden, nie mniej istotny, aspekt stosunków międzynarodowych, jakim jest zagadnienie percepcji. Warunkuje ono bowiem prowadzenie skutecznego dialogu pomiędzy państwami. Jest to szczególnie istotne w przypadku relacji bilateralnych pomiędzy Stanami Zjednoczonymi a Chińską Republiką Ludową, ponieważ błędne zdefiniowanie imperatywów polityki zagranicznej może mieć negatywne implikacje dla gospodarczego oraz politycznego status quo wielu regionów świata. 
Głównym celem niniejszego artykułu jest przedstawienie i omówienie wzajemnej percepcji obu państw na szczeblu rządowym oraz społecznym. Autor podejmie również próbę odpowiedzi na pytania o znaczenie gospodarki we wzajemnej percepcji oraz o rolę i wpływ państw trzecich na wzajemne postrzeganie. Natomiast, w celu uzyskania odpowiedzi na postawione pytania zostanie wykorzystana m.in. metoda analizy porównawczej.

\section{Interes narodowy}

Dnia 21 lutego 1972 roku, podczas spotkania z ówczesnym premierem Zhou Enlai'em, prezydent Richard Nixon wypowiedział następujące słowa: „wiemy, że głęboko wierzycie w swoje zasady. My głęboko wierzymy w nasze. Nie prosimy, żebyście odstąpili od swoich zasad, tak samo jak wy nie prosilibyście, żebyśmy odstąpili od naszych"1. Słowa, których 44 lata temu podczas swojej pierwszej podróży do Chin użył prezydent Nixon, oddają kwintesencję poszanowania dla odmienności kulturowych w relacjach pomiędzy państwami oraz stanowią swojego rodzaju bazę dla podjęcia próby rzetelnej analizy przesłanek, na których opierają się wzajemne interesy narodowe. Zaprezentowana powyżej pragmatyczna percepcja jest bardzo ważna po dzień dzisiejszy, ponieważ XXI wieku naprzeciw siebie stają dwa kraje, których gospodarki zajmują pierwsze (Stany Zjednoczone) oraz drugie miejsce na świecie (Chińska Republika Ludowa) $^{2}$. Wzajemna percepcja ma również przemożne znaczenie dla bezpieczeństwa tak w regionie Pacyfiku, jak i w pozostałych częściach świata. Roman Kuźniar podkreśla, że „bezpieczeństwo jest nieodłącznie związane z żywotnymi interesami narodowymi. Czasem określa się jako rację stanu, choć to pojęcie jest często nadużywane w doraźnych celach politycznych i należy zachować ostrożność zarówno w posługiwaniu się nim, jak i w jego recepcji w różnych kontekstach ideowych i politycznych"3. Wszystkie powyższe wypowiedzi wskazują na to, że wzajemna, prawidłowa percepcja mocarstw jest jedną z najważniejszych części składowych utrzymywania poprawnych relacji bilateralnych oraz multilateralnych.

$1 \quad$ S. E. Phillips, E. C. Keefer, Foreign Relations of the United States, 1969-1976, Volume XVII, China, 1969-1972, Washington 2006, t. 17, s. 688.

2 A. Willige, The world's top economy: the US vs. China in five charts, „World Economic Forum", 05.12.2016, https://www.weforum.org/agenda/2016/12/the-world-s-top-economy-the-us-vs-china-in-five-charts/ (dostęp: 05.07.2017).

3 R. Kuźniar, Bezpieczeństwo w stosunkach międzynarodowych, [w:] Stosunki międzynarodowe. Geneza, struktura, dynamika, E. Haliżak, R. Kuźniar (red.), Warszawa 2006, s. 143. 


\section{Wzajemna percepcja społeczeństw}

Bardzo ważne funkcje na polu społecznej percepcji odgrywają dwa czynniki: różnice kulturowe oraz mass media. Podkreślając znaczenie środków masowego przekazu trzeba zwrócić uwagę na bezprecedensowe wydarzenia, które wyraźnie odbiły swe piętno na opinii publicznej. Takim szczególnym punktem na mapie percepcji społeczeństwa amerykańskiego względem partnera chińskiego były wydarzenia z placu Tian’anmen w czerwcu 1989 roku, które postawiły dyplomację obu państw w bardzo niewygodnej sytuacji. Przyjmując za Henrym Kissingerem, iż ,jedną z przeszkód w utrzymaniu ciągłości amerykańskiej polityki zagranicznej jest radykalizm okresowych zmian rządu”", trzeba zwrócić uwagę na fakt, jak istotna dla zachowania ciągłości polityki jest opinia publiczna. Opinia publiczna, której bardzo bliskie są tzw. „amerykańskie ideały" przesiąknięte wartościami demokratycznymi, wolnością słowa oraz bezwzględną wolnością osobistą jednostki ${ }^{5}$. Dlatego też ówczesna administracja George'a Busha seniora została postawiona przed wyzwaniem, które można ująć w następujący sposób: jak skutecznie zarządzać nagłym kryzysem, kiedy jedna ze stron ( $w$ tym przypadku ChRL) doznaje znaczącej utraty wizerunku, w taki sposób, aby zachować ciągłość relacji przy jednoczesnym „zadośćuczynieniu” opinii publicznej, reprezentantom dwuizbowego kongre$\mathrm{su}^{6}$ oraz innym zainteresowanym podmiotom międzynarodowym. Jest to problem z jednej strony wymagający zręczności politycznej, z drugiej natomiast mocnej pozycji na rodzimej scenie politycznej. Wspomniany wcześniej Henry Kissinger podkreśla, że „W zależności od ugruntowania pozycji we własnym kraju ustępstwa konieczne z pragmatycznego punktu widzenia mogą być wykorzystane przez opozycję do udowodnienia słabości"7 . Jest to ewidentnym zagrożeniem dla stabilności relacji bilateralnych w obliczu bezprecedensowych

4 H. Kissinger, op. cit., s. 231.

5 The Ideals of America, „The Atlantic” http://www.theatlantic.com/magazine/archive/1902/12/the-ideals-of-america/376192/ (dostęp: 28.05.2016).

6 Jest to o tyle istotne, iż tak do Izby Reprezentantów, jak i do Senatu co 2 lata odbywają się wybory rotacyjne. Istnieje zatem groźba poważnych przetasowań sił pomiędzy republikanami a demokratami. To z kolei ma poważny wpływ na politykę prowadzoną przez administrację urzędującego prezydenta, ponieważ może mu ułatwić prowadzenie polityki bądź utrudnić. Dobrym przykładem związanym stricte z polityką zagraniczną jest chociażby procedura mianowania ambasadorów. Więcej o amerykańskim systemie wyborczym oraz wspomnianej procedurze można znaleźć na: https:// www.whitehouse.gov/1600/legislative-branch (dostęp: 10.05.2016).

7 H. Kissinger, op. cit., s. 274. 
wydarzeń, którymi bez wątpienia stała się kwestia masakry na placu Tian’anmen. Ponadto w wyniku bieżących okoliczności, działania podejmowane przez każdą ze stron stanęły przed wyzwaniem związanym ze zmienionym punktem odniesienia w nowej sytuacji międzynarodowej. W przypadku Stanów Zjednoczonych, po wydarzeniach z 4 czerwca 1989 roku, takim właśnie punktem odniesienia była opinia publiczna, która wyraźnie zmieniła swój stosunek do ChRL (wykres 1 oraz wykres 2). Co niemniej istotne, pomimo upływu ćwierćwiecza od wydarzeń z placu Tian’anmen, percepcja Chin przez społeczeństwo amerykańskie nie uległa daleko idącym zmianom.

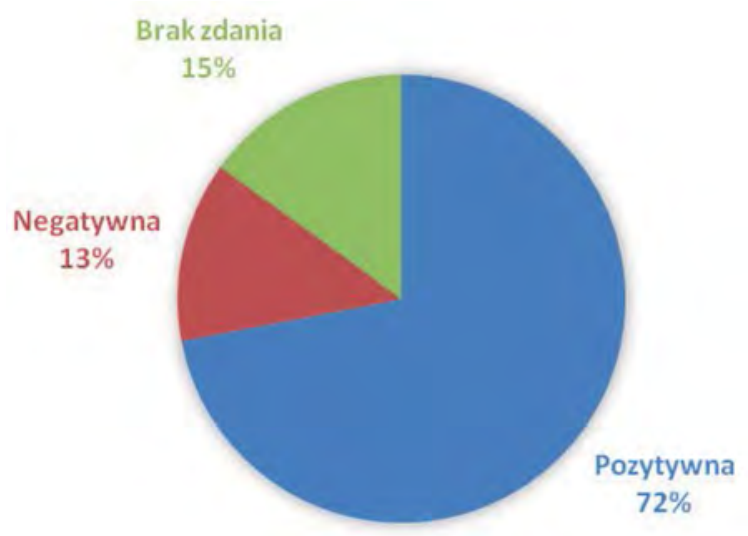

Wykres 1. Opinia obywateli amerykańskich o ChRL sprzed wydarzeń na placu Tian'anmen (początek 1989 roku)

Źródto: opracowanie własne na podstawie The Gallup Poll, Public Opinion 1989, Wilmington 1990, s. 98.

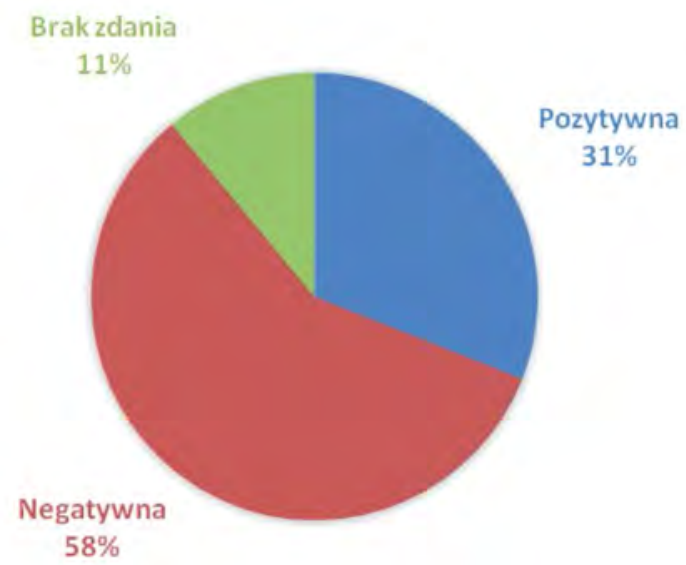

Wykres 2. Opinia obywateli amerykańskich o ChRL po wydarzeniach na placu Tian'anmen (sierpień 1989 roku)

Źródło: opracowanie własne na podstawie The Gallup Poll, Public Opinion 1989..., s. 180. 
Wydarzenia z placu Tian’anmen są dobrym przykładem radykalnej zmiany amerykańskiej opinii. Na pogłębienie negatywnej percepcji amerykańskiej opinii publicznej w kolejnych latach wpłynął także wzrost zadłużenia u partnera chińskiego, który w oczach wielu osób stanowi realne zagrożenie dla pozycji gospodarczej Stanów Zjednoczonych ${ }^{8}$.

Wykres 3 stanowi diagnozę percepcji Chin przez pryzmat ośmiu aspektów. Z kolei wykres 4 ukazuje różnice w percepcji obu nacji poprzez pryzmat wieku respondentów. Jak można zauważyć, młodsze osoby postrzegają drugą stronę o wiele korzystniej niż osoby doświadczone wiekiem.

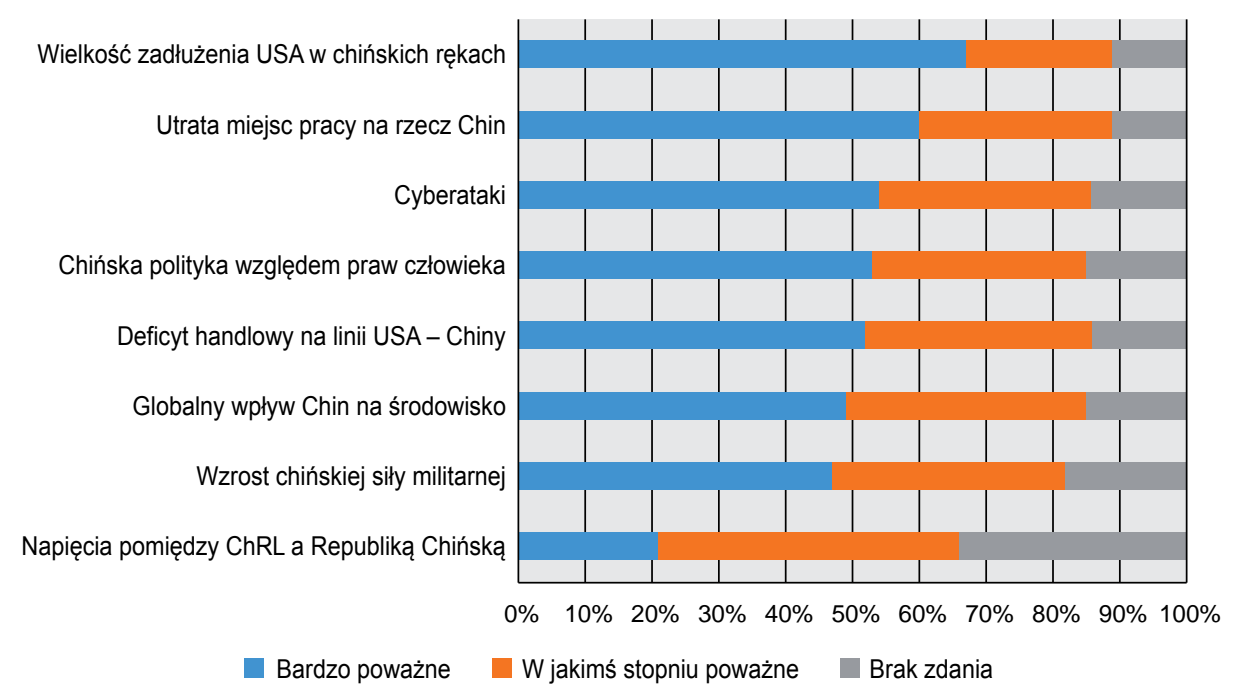

Wykres 3. Poziom zagrożenia wybranych aspektów z perspektywy amerykańskiej opinii publicznej Źródło: R. Wike, 6 facts about how Americans and Chinese see each other, Pew Research Center, 30.03.2016, http://www.pewresearch.org/fact-tank/2016/03/30/6-facts-about-how-americans-andchinese-see-each-other/ (dostęp: 05.05.2016).

Wykres 3 ukazuje, że opinia amerykańska najmniejsze zagrożenie ze strony Chin upatruje odpowiednio w relacjach ChRL z Tajwanem, negatywnym wpływie na środowisko, jak również w rosnącym znaczeniu chińskiej siły militarnej (niewykluczone, że jest to przejaw braku zainteresowania oraz odpowiedniego zasobu informacji). Niemniej jednak zwłaszcza ostatni aspekt jest bardzo znaczący z punktu widzenia amerykańskich interesów w rejonie Oceanu Pacyficznego oraz zachowania status quo w regionie. W tym miejscu należy podkreślić, że osoby odpowiedzialne za prowadzenie polityki

8 M. Egan, China is dumping U.S. debt, „CNN Money”, 11.09.2015, http://money.cnn. com/2015/09/10/inve sting/china-dumping-us-debt/ (dostęp: 04.05.2016). 
państwa, to właśnie aspekt związany z rosnącymi możliwościami wykorzystania sił zbrojnych przez partnera chińskiego postrzegają (obok zagadnień gospodarczych) jako bezpośrednie zagrożenie dla amerykańskich interesów. Pomimo, że wciąż istnieje znacząca dysproporcja sił pomiędzy armiami obu państw, to Chiny wyraźnie zwiększają inwestycje mające na celu rozbudowę potencjału militarnego'.

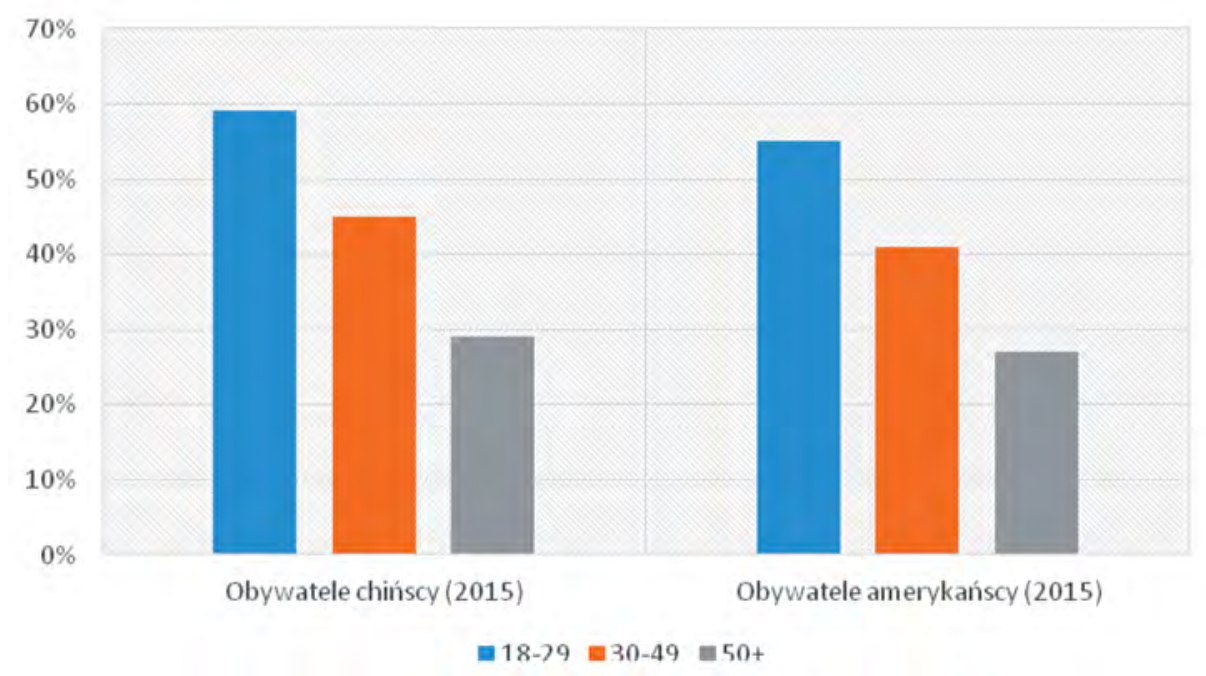

Wykres 4. Wzajemne pozytywne postrzeganie się obywateli obu państw według wieku, w procentach Źródło: R. Wike, 6 facts...

Natomiast powyższe badania przeprowadzone przez Pew Research Center wskazują, że to Chińczycy korzystniej odbierają obywateli Stanów Zjednoczonych, którzy z kolei od dłuższego czasu postrzegają Państwo Środka w bardziej negatywnym świetle. Uzupełnieniem wykresu 4 mogą być badania przeprowadzone w roku 2016 przez The Chicago Council on Global Affairs, z których wynika, że pomimo bardziej pozytywnego odbioru Stanów Zjednoczonych przez chińczyków, to aż $61 \%$ respondentów chińskich a $40 \%$ amerykańskich uważa, iż jednocześnie relacje pomiędzy oboma państwami uległy pogorszeniu ${ }^{10}$.

9 China's military budget over 3 times that of India, says Pentagon, „The Economic Times", 09.05.2015 http://economictimes.indiatimes.com/news/defence/chinas-military-budget-over-3-times-that-of-india-says-pentagon/articleshow/47215890.cms (dostęp: 10.11.2016).

10 K. Friedhoff, C. Kafura, Views From The G2:Public Opinion in the US \& China, https://www.thechicagoc ouncil.org/publication/views-g2-public-opinion-us-china (dostęp: 04.10.207). 
Wykres 5 prezentuje zmiany zachodzące w opinii Amerykanów na przestrzeni ostatnich 10 lat.

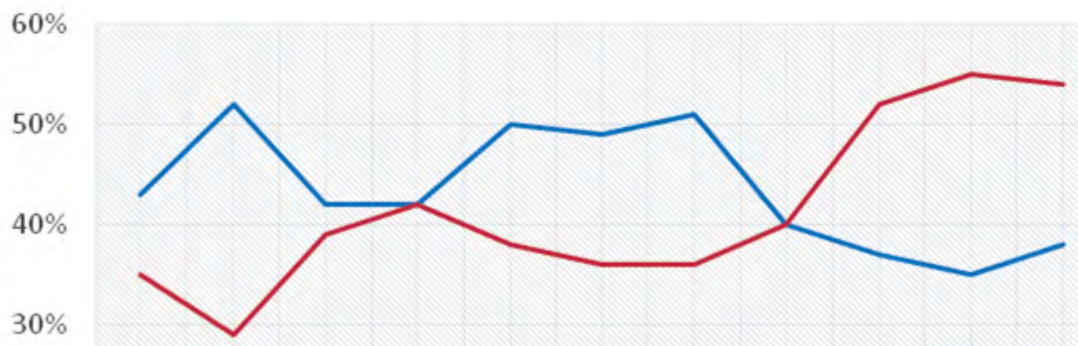

$20 \%$

$10 \%$

\begin{tabular}{|l|c|c|c|c|c|c|c|c|c|c|c|}
\hline $0 \%$ & 2005 & 2006 & 2007 & 2008 & 2009 & 2010 & 2011 & 2012 & 2013 & 2014 & 2015 \\
\hline Korzystnie & $43 \%$ & $52 \%$ & $42 \%$ & $42 \%$ & $50 \%$ & $49 \%$ & $51 \%$ & $40 \%$ & $37 \%$ & $35 \%$ & $38 \%$ \\
\hline Niekorzystnie & $35 \%$ & $29 \%$ & $39 \%$ & $42 \%$ & $38 \%$ & $36 \%$ & $36 \%$ & $40 \%$ & $52 \%$ & $55 \%$ & $54 \%$ \\
\hline
\end{tabular}

Wykres 5. Zmiany percepcji Chin przez obywateli Stanów Zjednoczonych

Źródło: R. Wike, Americans' Concerns about China: Economics, Cyberattacks, Human Rights Top the List, Pew Research Center, 09.09.2015, http://www.pewglobal.org/2015/09/09/americans-concerns-aboutchina-economics-cyberattacks-human-rights-top-the-list/ (dostęp: 06.05.2016).

Począwszy od 2011 roku obraz Chin w oczach Amerykanów ulegał systematycznemu pogorszeniu. Działo się tak przede wszystkim dlatego, że przeciętny obywatel czerpie wiedzę ze środków masowego przekazu, które z kolei używają uproszczeń oraz uogólnień. Zwrócił na to uwagę laureat Nagrody Nobla Daniel Kahneman, który podkreśla, że „przy podejmowaniu trudnych ocen [a zagadnienia związane z relacjami bilateralnymi należą do kwestii złożonych] ludzie używają podobieństwa (zgodności) jako upraszczającej heurystyki [uproszczonej reguły wnioskowania, którą posługujemy się w sposób nieświadomy], czyli czegoś w rodzaju „pi razy drzwi”. Używanie tej metody heurystycznej sprawia, że prognozy są obciążone dającym się przewidzieć skrzywieniem poznawczym (błędem systemowym)"11. Powyższy cytat zwraca uwagę na słabości, którym nie powinny podlegać osoby odpowiedzialne za kształtowanie polityki zagranicznej państwa.

$\mathrm{Na}$ poprzednich stronach został zaprezentowany problem wydarzeń z placu Tiananmen, gdzie odmienna percepcja skutkowała odmiennym

11 D. Kahneman, Pułapki myślenia: O myśleniu szybkim i wolnym, Poznań 2012, s. 15. 
podejściem do zaistniałej sytuacji. Mianowicie, reakcja ówczesnej administracji George’a Busha seniora kierowała się przede wszystkim interesem Stanów Zjednoczonych, czyli m.in. utrzymaniem ciągłości w relacjach wzajemnych z Chińską Republiką Ludową. Natomiast opinia publiczna kierowała się wspomnianymi przez Kahnemana uproszczeniami wynikającymi z braku odpowiedniej wiedzy. Podsumowując rolę społeczeństwa amerykańskiego w prowadzeniu polityki przez amerykańską administrację warto zwrócić uwagę na opinię byłego doradcy ds. bezpieczeństwa narodowego USA w administracji prezydenta Jimmy'ego Cartera, Zbigniewa Brzezińskiego, który wypowiedział następujące słowa: „bardzo mnie martwi, że większość obywateli USA praktycznie niczego nie wie o reszcie świata. Są ignorantami. To poważny problem w kraju, gdzie przeforsowanie polityki zagranicznej wymaga szerokiego poparcia opinii publicznej. W rezultacie każdemu prezydentowi będzie trudno zareagować inteligentną polityką na skomplikowane sprawy świata"12.

\section{Wzajemna percepcja państw}

Podejmując próbę przedstawienia wzajemnej percepcji państw trzeba zwrócić uwagę na fakt, iż Chiny są państwem ukształtowanym przez kulturę sięgającą ponad dwa tysiące lat. Nie mogą być zatem postrzegane w oderwaniu od tejże wielowiekowej tradycji, ponieważ może to skutkować błędnym odbiorem ich intencji. Jak podkreśla Bogdan Góralczyk ${ }^{13}$, Chiny winny być postrzegane jako starożytna cywilizacja licząca sobie kilka tysięcy lat ${ }^{14}$. Taki odbiór Chińskiej Republiki Ludowej pomoże w lepszym stopniu zrozumieć różnice występujące pomiędzy nimi a Stanami Zjednoczonymi.

Dobrym przykładem różnic występujących pomiędzy państwami jest podejście do dyplomacji opisane przez Henry’ego Kissingera, który podkreśla, że „główna różnica między chińską a zachodnią strategią dyplomatyczną polega na różnicy w reakcji na potencjalne zagrożenie. Zachodni dyplomaci uznają, że powinni działać ostrożnie, unikając prowokacji. Chiński sposób reagowania na ogół zwiększa opór. Niekorzystny układ sił każe zachodnim

12 J. Stanton, Brzezinski Vision for a Power Sharing World Stymied by Ignorant Americans Leaders, Citizens, „Counter Punch”, 26.08.2016, http://www.counterpunch. org/2016/08/26/brzezinski-vision-for-a-power-sharing-world-stymied-by-ignorant-americans-leaders-citizens/ (dostęp: 10.11.2016).

13 Sinolog oraz politolog z Uniwersytetu Warszawskiego, były ambasador Polski w Tajlandii (przyp. autora).

14 Słowa wypowiedziane podczas Academy of Young Diplomats, Warszawa, 17 grudnia 2015. 
dyplomatom szukać rozwiązania na drodze dyplomatycznej: zachęcają do dyplomatycznych wystąpień, które mają przedstawić drugą stronę jako "złą», by odizolować ją moralnie, ale zarazem zniechęcić do użycia siły [...]. Chińscy stratedzy zwykle wolą raczej okazać męstwo i zastosować psychologiczne środki nacisku niż przyznać, że przeciwnik ma przewagę. Wierzą w odstraszanie w formie uprzedzania działań adwersarza. Gdy chińscy planiści uznają, że przeciwnik uzyskał zbyt dużą przewagę i że może się zwrócić przeciwko Chinom, próbują podkopać morale nieprzyjaciela i zdobyć psychologiczną, a najlepiej także moralną, dominację"15. Jak można zauważyć, różnica pomiędzy Stanami Zjednoczonymi a Chinami jest w tej kwestii zasadnicza. Podobna różnica występuje również $\mathrm{w}$ postrzeganiu oraz ocenie obecnego porządku międzynarodowego, który w znacznej mierze nabrał kształtów wraz z decyzjami podjętym po zakończeniu II wojny światowej ${ }^{16}$. Otóż Stany Zjednoczone jeszcze przed rokiem 1945 stały się jednym z głównych architektów obecnego kształtu świata opartego o instytucje międzynarodowe, z których najważniejszą funkcję (z politycznego punktu widzenia) pełni Organizacja Narodów Zjednoczonych. Pomimo, że Chińska Republika Ludowa znajduje się wśród pięciu stałych członków Rady Bezpieczeństwa, to Republika Chińska do października 1971 roku zasiadała wśród „wielkiej piątki” ${ }^{17}$. Trzeba pamiętać, że obecna koncepcja świata w znacznej mierze powstawała bez udziału Chińskiej Republiki Ludowej, która do momentu zbliżenia ze Stanami Zjednoczonymi na początku lat 70. XX wieku przypieczętowanego wizytą prezydenta Nixona w Pekinie w 1972 roku, pozostawała niemalże w całkowitej izolacji państw świata zachodniego. Nie oznacza to, że Chiny całkowicie negują myśl liberalną ${ }^{18}$, która przewodziła Stanom Zjednoczonym, po prostu czują się mniej związane z panującym porządkiem, w którego ustalaniu nie brały udziału. Można zwrócić uwagę na dwa następujące

15 H. Kissinger, op. cit., s. 350.

16 History of the United Nations, United Nations, http://www.un.org/en/sections/history/history-united-nations/ (dostęp: 09.05.2016).

17 Po proklamowaniu przez Mao Zedonga Chińskiej Republiki Ludowej w 1949 roku, siły popierane przez Stany Zjednoczone z Czang Kaj-szekiem na czele zostały zmuszone do ucieczki na Tajwan. Utworzona tam Republika Chińska do 1971 roku reprezentowała Chiny w Radzie Bezpieczeństwa ONZ. Status quo uległo zmianie wraz z reorientacją polityki zagranicznej USA oraz pod wpływem nacisków prowadzonych przez ChRL (przyp. autora).

18 Więcej na temat w: A. Moravcsik, Liberalism and International Relations Theory, Harvard University and University of Chicago, Paper No. 92-6, Cambridge, https://www. princeton.edu/ amoravcs/library/liberalism_working.pdf (dostęp: 10.05.2016). 
zagadnienia, przyjmując punkt widzenia strony chińskiej, przemawiające przeciwko liberalnemu porządkowi międzynarodowemu:

1. Powstał on poza kręgiem kulturowym, z którego wywodzą się chińska kultura oraz konfucjanizm;

2. Liberalne idee zaakceptowane na forum międzynarodowym mogą okazać się zagrożeniem dla wewnętrznej polityki oraz chińskiego systemu politycznego jako całości. Dopuszczają one bowiem dyskusję na takie tematy jak m.in.: mniejszości narodowe, etniczne, językowe oraz religijne, które co pewien czas powracają jako przedmiot sporów wewnętrznych (przykład Falun Gong ${ }^{19}$ ) oraz wyzwań na linii Waszyngton-Pekin.

Jednakże nie oznacza to, że Chiny dawały skuteczny wyraz swej odmiennej percepcji wraz z proklamowaniem w 1949 roku Chińskiej Republiki Ludowej. Dopiero po umocnieniu przywództwa w 1978 roku przez Denga Xiaopinga rozpoczął się proces przemian, a Państwo Środka zaczęło niwelować zapóźnienia gospodarcze (głównie poprzez politykę „Pokojowego Wzrostu”20), co pozwoliło na prowadzenie skuteczniejszej polemiki z Amerykanami. Pomimo odmiennego postrzegania ładu międzynarodowego, Stany Zjednoczone „pomogły Chinom stać się częścią globalnej gospodarki: zapewniły im dostęp do rynków, kapitału oraz technologii. Wyszkoliły chińskich ekspertów z zakresu nauki, technologii i prawa międzynarodowego"21. Stany Zjednoczone były postrzegane przez Chiny jako niezbędny element dla wprowadzania reform w sferze ekonomicznej, natomiast Ameryka postrzegała ChRL jako trudny do przecenienia „teren inwestycyjny”. Pod koniec lat 70. rozpocząl się okres kooperacji gospodarczej, który zdefiniuje późniejsze relacje obu państw jako neither friends nor foes ${ }^{22}$. Oznacza to, iż oba podmioty prawa międzynarodowego nie postrzegały siebie jako sojuszników z jednej strony, z drugiej natomiast nie uważały jako zagrożenie dla fundamentalnych wartości. Był to niewątpliwie okres, w którym wzajemna percepcja opierała się m.in. na zasadzie, iż brak powściągliwości w małych sprawach niszczy wielkie plany. W przypadku polityki prowadzonej między państwami, które dopiero kilka

19 P. Beaumont, China's Falun Gong crackdown: 'The persecution is almost underground', „The Guardian”, 18.07.2009, http://www.theguardian.com/world/2009/jul/18/ china-falun-gong-crackdown (dostęp: 08.05.2016).

20 J. Skrzyp, Wielki marsz Państwa Środka ku pozycji globalnego ośrodka siły, „Przegląd Polityczny" 2012, t. 5, s. 42.

21 A. J. Nathan, A. Scobell, How China Sees America, „Foreign Affairs” September/October 2012, nr 5, s. 35.

22 China Cross Talk: The American Debate over China Policy since Normalization. A Reader, S. Kennedy (red.), Lanham 2003, s. 303. 
lat wcześniej nawiązały oficjalne stosunki dyplomatyczne, trudno jest uniknąć lawirowania pomiędzy drażliwymi tematami mogącymi stanąć na przeszkodzie umacnianiu więzi. Mówiąc o Chińskiej Republice Ludowej takim zagadnieniem były kwestie związane m.in. z poszanowaniem praw człowieka, które mimo iż poruszane, były wyraźnie marginalizowane. Jest to o tyle istotne, że kiedy stosunki bilateralne plasują się na w miarę poprawnym poziomie, wpływa to korzystnie na wzajemną percepcję. Idealną sytuacją dla stabilności stosunków bilateralnych jest postępowanie wedle zasady wyznawanej swojego czasu przez Denga Xiaopinga, iż „tym, co się liczy, są rezultaty, a nie doktryna, zgodnie z którą się je osiąga" ${ }^{23}$. Jednakże pomimo współpracy, która układała się w miarę harmonijnie trzeba zaznaczyć, że już wtedy zarysowały się pewne kwestie, które będą rzutowały na obecny stan relacji bilateralnych. Wśród wielu zagadnień należy wspomnieć o tych stanowiących swojego rodzaju sui generis wzajemnej percepcji:

1) odmienne postrzeganie politycznych wartości i wolności obywatelskich;

2) odmienne koncepcje funkcjonowania świata w XXI wieku;

3) odmienne poglądy na temat bezpieczeństwa (obecnie Stany Zjednoczone i ChRL postrzegają się jako rosnące zagrożenie dla stabilizacji regionu Pacyfiku);

4) status prawny oraz przyszłość Tajwanu (bardzo duże znaczenie ma kontekst najnowszych wyborów przeprowadzonych w Republice Chińskiej);

5) zaangażowanie Stanów Zjednoczonych w rejonie Pacyfiku (najnowszym tego przykładem jest zniesienie przez prezydenta Baracka Obamę embarga zakazującego eksportu broni do Wietnamu ${ }^{24}$ );

6) problemy z ochroną własności intelektualnej w ChRL.

Do powyższych punktów należałoby dodać jeszcze jeden, związany stricte z kwestiami ekonomicznymi. Otóż Stany Zjednoczone postrzegają Chińską Republikę Ludową jako zagrożenie dla swoich interesów gospodarczych. Przejawia się to przede wszystkim w trzech zagadnieniach. Pierwszym z nich jest negatywny bilans handlowy, który wyniósł niemalże 366 mld USD za rok $2015^{25}$. Pomimo, że zmalał on w porównaniu z rokiem 2014 o 22,6 mld USD, nie jest to dobrym znakiem dla amerykańskiej gospodarki, ponieważ

23 H. Kissinger, op. cit., s. 439.

24 G. Harris, Vietnam Arms Embargo to Be Fully Lifted, Obama Says in Hanoi, „The New York Times", 23.05.2016, http://www.nytimes.com/2016/05/24/world/asia/vietnam-us-arms-embargo-obama.html?_r=0 (dostęp: 23.05.2016).

25 T. P. Jeffrey, \$365,694,500,000: U.S. Merchandise Trade Deficit With China Hit Record in 2015, „CNS News”, 09.02.2016, http://cnsnews.com/news/article/terence-p-jeffrey/ 365694500000-merchandise-trade-deficit-china-hit-record-2015 (dostęp: 11.05.2016). 
spadek zaliczył zarówno eksport, jak i import. Ponadto przedmiotem sporu wciąż pozostaje wartość chińskiej waluty (renminbi), która, utrzymywana na sztucznym poziomie przez rząd w Pekinie, jest niedowartościowana. Fakt ten skutecznie utrudnia zwiększenie amerykańskiego eksportu. Drugim zagadnieniem dotyczącym gospodarki jest bardzo słaba ochrona własności intelektualnej w Chinach oraz zakrojone na szeroką skalę szpiegostwo gospodarcze. Bardzo dobrym przykładem jest sytuacja, w której znalazła się firma Segway. Otóż oskarżyła ona chińskie przedsiębiorstwo Ninebot o kradzież patentu do produkcji dwukołowych pojazdów elektrycznych. W międzyczasie Ninebot stał się na tyle popularny, że w roku 2015 złożył propozycję wykupu Segway’a de facto za środki, które w pewnej części pochodziły z nielegalnego wykorzystania know-how obecnie chińskiej firmy ${ }^{26}$. Nie jest to przypadek odosobniony i jednoznacznie negatywnie odbija się na postrzeganiu Chin przez Stany Zjednoczone. Jest to również ostrzeżenie dla potencjalnych inwestorów, aby przedsięwzięli odpowiednie środki zaradcze, zwłaszcza w kwestii planów zawiązania spółki typu joint-venture ${ }^{27}$. Ostatnim znaczącym aspektem gospodarczym odbieranym negatywnie przez Stany Zjednoczone są chińskie plany odnośnie One Belt, One Road ${ }^{28}$, New Silk Road ${ }^{29}$ oraz powołanie do życia w 2015 roku Azjatyckiego Banku Inwestycji Infrastrukturalnych (AIIB), który jest postrzegany jako konkurencja dla Banku Światowego (BŚ), w którym to Stany Zjednoczone mają znaczący głos. Pomimo, iż sama działalność AIIB dopiero się rozpoczyna, to trzeba zauważyć, iż w poczet członków założycieli weszły kraje postrzegane za kluczowych sojuszników USA: Niemcy, Francja czy Wielka Brytania. Stało się tak pomimo nacisków Ameryki. Obecnie jedynym państwem, które nie jest (jeszcze) członkiem AIIB, a należy do kluczowych amerykańskich sojuszników, jest Japonia.

Kolejnym wyzwaniem dla pozytywnej percepcji jest kwestia Tajwanu, będąca od samego początku (od roku 1949) swojego rodzaju „węzłem

26 M. Kan, Segway now a Chinese company after acquisition by Ninebot, „Computerworld”, 15.04.2016, http://www.computerworld.com/article/2909562/segway-now -a-chinese-company-after-acquisition-by-ninebot.html (dostęp: 11.05.2016).

27 Joint Venture - JV, „Investopedia”, http://www.investopedia.com/terms/j/jointventure.asp?layout=orig (dostęp: 11.05.2016).

28 C. Putz, China Pushes One Belt, One Road in Central Asia, „The Diplomat”, 24.05.2016, http://thediplomat.com/2016/05/china-pushes-one-belt-one-road-in-central-asia/ (dostęp: 26.05.2016).

29 H. H. Wang, China's Triple Wins: The New Silk Roads, „Forbes”, 15.01.2016, http:// www.forbes.com/sites/helenwang/2016/01/15/chinas-triple-wins-the-new-silk-roads/\#201ef557520b (dostęp: 25.04.2016). 
gordyjskim", którego koncepcje rozwiązania różnią się od siebie w sposób znaczący. Mianowicie ChRL jest zwolenniczką One China Policy, która ma na celu powolne zjednoczenie wyspy Tajwan z kontynentem. Wydawało się, że zwiększanie zależności Republiki Chińskiej od Chińskiej Republiki Ludowej będzie nieuchronnie prowadziło ku unifikacji. Zwłaszcza po spotkaniu, które odbyło się 7 listopada w 2015 roku pomiędzy prezydentem Republiki Chińskiej Ma Ying-jeou a przewodniczącym Komunistycznej Partii Chin Xi Jinpingiem $^{30}$. Również $\mathrm{w}$ tym samym roku podpisano gospodarczą umowę bilateralną, która zbliżała oba państwa do siebie. Wszystkie te działania były niejako zwieńczeniem drugiej i ostatniej kadencji prezydenta Ma Ying-jeou. Podniosły one również rangę wzajemnych relacji, ponieważ wspomniane spotkanie głów obu państw było pierwszym na tak wysokim szczeblu. Zostało ono odnotowane przez Stany Zjednoczone, które wydały krótki komunikat, iż oczekują „po obu stronach konstruktywnego dialogu, opartego na wzajemnym zrozumieniu, godności i szacunku" ${ }^{31}$. Mogło się wydawać, że kwestia Tajwanu nie będzie aż tak bardzo dzieliła obu państw. Jednak wraz z wynikami wyborów prezydenckich oraz parlamentarnych przeprowadzonych w 2016 roku na Tajwanie, rządząca partia Kuomintang (z której szeregów wywodził się ówczesny prezydent Ma Ying-jeou) straciła po raz pierwszy większość w parlamencie na rzecz opozycyjnej Demokratycznej Partii Postępowej (DPP). Jest to znaczące dla status quo regionu, ponieważ jednym z głównych postulatów DPP jest zwrot ku m.in. Japonii, Stanom Zjednoczonym i państwom Zachodu. Natomiast nowa prezydent kraju Tsai Ing-wen wielokrotnie wypowiadała się, że jest za umacnianiem niepodległości Tajwanu, co jest odbierane bardzo chłodno przez Pekin. Ponadto Departament Stanu USA odniósł się do zwycięstwa Tsai Ing-wen w następujących słowach: „podzielamy głębokie zainteresowanie Tajwańczyków kontynuacją pokojowych i stabilnych relacji chińsko-tajwańskich. Oczekujemy na współpracę dr Tsai i wszystkich partyjnych przywódców na Tajwanie w celu dalszego wzmocnienia nieoficjalnych relacji między Stanami Zjednoczonymi a Tajwańczykami”32. Reakcja chińskiego Ministerstwa Spraw Zagranicznych była

30 Ch. Hutzler, China's Xi Jinping and Taiwan's Ma Ying-jeou Meet in Singapore, „The Wall Street Journal", 08.11.2015, http://www.wsj.com/articles/china-s-xi-jinping-and-taiwan-s-ma-ying-jeou-meet-in-singapore-1446880724 (dostęp: 12.05.2016).

31 U.S. encourages 'constructive dialogue' ahead of Ma-Xi meeting, „Focus Taiwan”, 04.11.2015, http://focustaiwan.tw/news/acs/201511040015.aspx (dostęp: 12.05.2016).

32 J. Kirby, On Taiwan's Election, U.S. Department of State, 16.01.2016, http://www.state. gov/r/pa/prs/ps/2016/01/251328.htm (dostęp: 14.05.2016). 
znacząco odmienna: „na świecie są tylko jedne Chiny, kontynent oraz Tajwan należą do jednych Chin a chińska suwerenność i integralność terytorialna nie będzie tolerowana”33. Bogdan Góralczyk skomentował, iż „pewne kroki Tsai Ing-wen i jej partii jednoznacznie wskazują na to, w jaki sposób będą kształtowały się relacje Tajwanu z Chińską Republiką Ludową" ${ }^{34}$. Zaistniała sytuacja może przyczynić się jedynie do pogłębienia rozbieżności zdań oraz wzrostu nieufności na linii Waszyngton-Pekin, ponieważ Chiny już postrzegają amerykańską obecność w Azji jako zagrożenie ${ }^{35}$. Natomiast możliwość potencjalnego rozszerzenia strefy wpływów przez USA wobec sprzyjającej konfiguracji politycznej w Republice Chińskiej może zostać odebrana co najmniej negatywnie.

Pozostaje jeszcze kwestia zbliżenia Republiki Chińskiej z Japonią, która jest $\mathrm{z}$ kolei największym sojusznikiem Stanów Zjednoczonych w regionie. Trzeba odpowiedzieć na pytanie, czy nie ma w tej całej sytuacji analogii do tzw. „Pułapki Tukidydesa”, kiedy wzrost potęgi Aten powodował wzrost poczucia zagrożenia w Sparcie co w konsekwencji skończyło się trwającym 27 lat konfliktem zbrojnym. Warto również zauważyć, iż zaprzysiężona dnia 20 maja 2016 roku prezydent Tsai pozostaje w dobrych relacjach $\mathrm{z}$ obecnym premierem Japonii Abe Shinzo, co czyni konfigurację sił jeszcze bardziej niekorzystną dla Chińskiej Republiki Ludowej. Dodając do tego fakt, iż przyjęcie przez japoński parlament krytykowanych przez stronę chińską tzw. security bills $^{36}$, spotkało się z pozytywnym odbiorem Stanów Zjednoczonych, można postawić hipotezę, iż region Azji Wschodniej staje się areną poważnych wyzwań dla obu państw, co nie pozostanie bez wpływu na wzajemną percepcję.

Na niekorzystne postrzeganie Stanów Zjednoczonych przez Chiny wpływa również aktywność Amerykanów m.in. na Morzu Wschodniochińskim. Wielokrotne incydenty dowodzą, że jedna jak i druga strona skutecznie daje

33 J. Pomfret, After vote, China tells Taiwan to abandon independence "hallucination", „Reuters”, 17.01.2016, http://www.reuters.com/article/taiwan-election-idUSKCNOUV02I (dostęp: 14.05.2016).

34 Inni Chińczycy. Pogorszenie relacji Tajwan-Chiny?, „Polskie Radio. Dwójka”, 20.01.2016, http://www.polskieradio.pl/8/3660/Artykul/1572540,Inni-Chinczycy -Pogorszenie-relacji-TajwanChiny (dostęp: 14.05.2016).

35 H. Cooper, Challenging Chinese Claims, U.S. Sends Warship Near Artificial Island Chain, „The New York Times”, 26.10.2015, http://www.nytimes.com/2015/10/27/ world/asia/challenging-chinese-claims-us-sends-warship-near-artificial-island-chain.html (dostęp: 10.05.2016).

36 Japan to allow military role overseas in historic move, „BBC News”, 18.09.2015, http:// www.bbc.com/news/world-asia-34287362 (ostatni dostep 05.05.2016). 
do zrozumienia, iż kwestia bezpieczeństwa regionu jest dla nich bardzo istotna, jednak postrzegana w odmienny sposób ${ }^{37}$.

Z kolei dla Chin (oraz poniekąd dla samej Ameryki) dużą niewiadomą pozostaje polityka przyszłego prezydenta Stanów Zjednoczonych. W zależności od wyniku wyborów postrzeganie Ameryki przez ChRL może ulec bądź diametralnej zmianie (w przypadku zwycięstwa kandydata republikanów Donalda Trumpa), bądź będzie mniej więcej oscylowało wokół obecnego poziomu w przypadku sukcesu demokraty. Natomiast wielokrotne prowokacyjne wypowiedzi republikańskiego kandydata, pod adresem ChRL typu: „nie możemy pozwolić, aby Chiny wciąż okradały nasze państwo"38 mogą wydawać się niepokojące. Słowa Donalda Trumpa są również szkodliwe dla demokratycznych ruchów oraz prodemokratycznych organizacji działających w Chinach. Pokazują one bowiem, że demokracja może okazać się nieprzewidywalna.

\section{Podsumowanie}

Zaprezentowane powyżej wyzwania stojące na drodze ku polepszeniu stosunków amerykańsko-chińskich nie stają się łatwiejsze, wręcz przeciwnie - uległy one komplikacji za sprawą ostatnich wydarzeń na arenie międzynarodowej oraz poprzez posunięcia $\mathrm{w}$ polityce wewnętrznej Pekinu oraz Waszyngtonu. Decyzje te nie ułatwiają wspólnego dialogu. Niemniej jednak „początki” wzajemnych relacji tuż po wizycie prezydenta Richarda Nixona w 1972 roku oraz ich zintensyfikowanie po roku 1978 ukazują, iż możliwym jest przedkładanie budowania wzajemnych relacji nad problemy wywołujące kontrowersje. Jest to bardzo istotne dla kwestii związanych $\mathrm{z}$ bezpieczeństwem międzynarodowym, ponieważ w przypadku konfliktu tych dwóch mocarstw, inni gracze stosunków międzynarodowych zostaną zmuszeni do opowiedzenia się po którejś ze stron, czego prawdopodobnie woleliby uniknąć. Jednakże można również zaobserwować bardziej pozytywne aspekty w stosunkach bilateralnych świadczące, iż wzajemna percepcja opiera się na pewnym pragmatyzmie, który nie pozwala „posunąć się o jeden krok za daleko”. Takim przejawem może być wymiana wzajemnych uprzejmości, jak

37 F. S. Gady, US Carrier Strike Group Arrives in South China Sea to Deter China, „The Diplomat", 05.03.2016, http://thediplomat.com/2016/03/us-carrier-strike-group-arrives-in-south-china-sea-to-deter-china/ (dostęp: 05.05.2016).

38 J. Diamond, Trump: 'We can't continue to allow China to rape our country', „CNN Politics”, 02.05.2016, http://edition.cnn.com/2016/05/01/politics/donald-trump-china-rape/ (dostęp: 15.05.2016). 
podczas wizyty Xi Jinpinga w siedzibie Organizacji Narodów Zjednoczonych we wrześniu 2015 roku. Mimo, iż spotkanie miało charakter symboliczny, a nie roboczy, to świadczy o wyżej wspomnianym pragmatyzmie, ponieważ gdyby we wzajemnej percepcji przeważała jednoznacznie negatywna ocena, spotkanie w Białym Domu nie doszłoby do skutku.

Niemniej jednak pozostaje faktem, że obecnie (2017 r.) Stany Zjednoczone oraz Chińska Republika Ludowa postrzegają się nieco bardziej negatywnie, a ich stosunki opierają się na pewnej dozie nieufności. Percepcja uległa zdecydowanemu pogorszeniu i jest bardziej negatywna niż w roku 1978, jednakże rosnące powiązania gospodarcze wciąż spełniają dodatkową funkcję hamulca bezpieczeństwa dla decyzji politycznych. Chiny w ciągu ostatnich lat stały się największym wierzycielem świata, jednakże w tym samym czasie znacząco uzależniły się od eksportu m.in. do Stanów Zjednoczonych. Ważnym jest, aby oba państwa pamiętały o starym chińskim przysłowiu, które zwraca uwagę, że „władca nie może rozpętać wojny, bo się zezłościł. Wódz nie może rozpętać bitwy, bo się obraził. Gniew ostygnie, obraza przejdzie, ale zniszczone państwo się nie odrodzi, a zabici nie wrócą do życia”. Dlatego tak niezmiernie ważnym jest zbudowanie wzajemnych relacji na właściwej percepcji, która z kolei oparta być powinna nie tylko na zagrożeniach wynikających ze spraw bieżących, ale również na pragmatyzmie.

\section{Bibliografia}

BEAUMONT P., China's Falun Gong crackdown: 'The persecution is almost underground', „The Guardian”, 18.07.2009, http://www.theguardian.com/ world/2009/jul/18/china-falun-gong-crackdown.

COOPER H., Challenging Chinese Claims, U.S. Sends Warship Near Artificial Island Chain, „The New York Times”, 26.10.2015, http://www.nytimes. com/2015/10/27/world/asia/challenging-chinese-claims-us-sends-warship-near-artificial-island-chain.html

DIAMOND J., Trump: 'We can't continue to allow China to rape our country', „CNN Politics” 02.05.2016, http://edition.cnn.com/2016/05/01/politics/ donald-trump-china-rape/.

EGAN M., China is dumping U.S. debt, „CNN Money”, 11.09.2015, http:// money.cnn.com/2015/09/10/investing/china-dumping-us-debt/.

FEARON J., A Conversation with Kenneth Waltz, „Annual Reviews”, 06.2012, http://www.annualreviews.org/doi/pdf/10.1146/annurev-polisci-020511-174136. 
FRIEDHOFF K., KAFURA C., Views From The G2: Public Opinion in The US \& China, https://www.thechicagocouncil.org/publication/viewsg2-public-opinion-us-china.

GADY F. S., US Carrier Strike Group Arrives in South China Sea to Deter China, „The Diplomat”, 05.03.2016, http://thediplomat.com/2016/03/uscarrier-strike-group-arrives-in-south-china-sea-to-deter-china/.

HARRIS G., Vietnam Arms Embargo to Be Fully Lifted, Obama Says in Hanoi, „The New York Times”, 23.05.2016, http://www.nytimes.com/2016/05/24/ world/asia/vietnam-us-arms-embargo-obama.html?_r=0.

HISTORY of the United nations, „United Nations” http://www.un.org/en/sections/history/history-united-nations/.

HUTZLER Ch., China's Xi Jinping and Taiwan's Ma Ying-jeou Meet in Singapore, „The Wall Street Journal”, 08.11.2015, http://www.wsj.com/articles/china-s-xi-jinping-and-taiwan-s-ma-ying-jeou-meet-in-singapore-1446880724.

THE Ideals of America, „The Atlantic” http://www.theatlantic.com/magazine/archive/1902/12/the-ideals-of-america/376192/.

INNI Chińczycy. Pogorszenie relacji Tajwan-Chiny?, „Polskie Radio. Dwójka”, 20.01.2016, http://www.polskieradio.pl/8/3660/Artykul/1572540,InniChinczycy-Pogorszenie-relacji-TajwanChiny.

JEFFREY T. P., \$365,694,500,000: U.S. Merchandise Trade Deficit With China Hit Record in 2015, „CNS News” z 09.02.2016, http://cnsnews.com/ news/article/terence-p-jeffrey/365694500000-merchandise-trade-deficit-china-hit-record-2015.

JOINT Venture - JV, „Investopedia” http://www.investopedia.com/terms/j/ jointven ture.asp?layout $=$ orig.

JAPAN to allow military role overseas in historic move, „BBC News”, 18.09.2015, http://www.bbc.com/news/world-asia-34287362.

KAHNEMAN D., Pułapki Myślenia: O myśleniu szybkim i wolnym, Poznań 2012.

KAN M., Segway now a Chinese company after acquisition by Ninebot, „Computerworld”, 15.04.2016, http://www.computerworld.com/article/2909562/segway-now-a-chinese-company-after-acquisition-by-ninebot.html.

KENNEDY S., China Cross Talk: The American Debate over China Policy since Normalization, Maryland 2003.

KIRBY J., On Taiwan's Election, „U.S. Department of State” 16.01.2016, http:// www.state.gov/r/pa/prs/ps/2016/01/251328.htm.

KISSINGER H., O Chinach, Wydawnictwo Czarne, Wołowiec 2014. 
KUŹNIAR R., Bezpieczeństwo w stosunkach międzynarodowych, [w:] Stosunki międzynarodowe. Geneza, struktura, dynamika, E. Haliżak, R. Kuźniar (red.), Warszawa 2006.

MORAVCSIK A., Liberalism and International Relations Theory, Harvard University, Cambridge https://www.princeton.edu/ amoravcs/library/liberalism_working.pdf.

NAJWIĘKSZE gospodarki na świecie, „Money.pl”, 26.12.2014 http://www. money.pl/gospodarka/wiadomosci/artykul/najwieksze-gospodarki-na -swieciezobacz, 102,0,1683558.html.

NATHAN A. J., SCOBELL A., How China Sees America, „Foreign Affairs”, September/October 2012, nr 5.

POMFRET J., After vote, China tells Taiwan to abandon independence "hallucination”, „Reuters” z 17.01.2016, http://www.reuters.com/article/taiwan-election-idUSKCNOUV02I.

PUTZ C., China Pushes One Belt, One Road in Central Asia, „The Diplomat”, 24.05.2016, http://thediplomat.com/2016/05/china-pushes-one-belt-one -road-in-central-asia/.

REALIZM Strukturalny, „Stosunki Międzynarodowe”, http://stosunki-miedzynarodowe.pl/slownik/64-r/1367-realizm-strukturalny.

SKRZYP J., Wielki Marsz Państwa Środka Ku Pozycji Globalnego Ośrodka Sity, Przegląd Polityczny, t. 5, 2012.

U.S. encourages 'constructive dialogue' ahead of Ma-Xi meeting, Focus Taiwan', 04.11.2015, http://focustaiwan.tw/news/acs/201511040015.aspx.

WANG H. H., China's Triple Wins: The New Silk Roads, „Forbes”, 15.01.2016, http://www.forbes.com/sites/helenwang/2016/01/15/chinas-triple-wins -the-new-silk-roads/\#201ef557520b. 